\title{
Application of PROMETHEE method for green supplier selection: a comparative result based on preference functions
}

\author{
Lazim Abdullah $^{1}$ (D) Waimun Chan ${ }^{1} \cdot$ Alireza Afshari $^{2}$
}

Received: 7 May 2018 / Accepted: 17 August 2018/Published online: 30 August 2018

(C) The Author(s) 2018

\begin{abstract}
The PROMETHEE is a significant method for evaluating alternatives with respect to criteria in multi-criteria decisionmaking problems. It is characterized by many types of preference functions that are used for assigning the differences between alternatives in judgements. This paper proposes a preference of green suppliers using the PROMETHEE under the usual criterion preference functions. Comparable results are presented to check the effect of different preference functions on the final preference. Seven economical and environmental criteria, four suppliers and five decision makers were the main structures in the green supplier selection problem. Data were collected via personal communication with decision makers using five-point Likert scale. The algorithm of PROMETHEE under usual criterion function was implemented, and the results show that supplier $A_{1}$ is the most preferred alternative. Comparative results also show that supplier $A_{1}$ is the most preferred alternative despite the difference in preference functions used.
\end{abstract}

Keywords Preference function · Decision making · Green supplier selection · Outranking · PROMETHEE

\section{Introduction}

Multi-criteria decision-making (MCDM) method is referred as a method used for scoring or ranking a finite number of alternatives by considering multiple criteria attached to the alternatives. MCDM concerns with evaluating and selecting alternatives that fit with the goals and necessity. There are many MCDM methods available in the literature whereby PROMETHEE is one of the MCDM methods. The PROMETHEE is the abbreviation of preference ranking organization method for enrichment evaluation. It is a ranking method which is considered as simple in

Lazim Abdullah

lazim_m@umt.edu.my

Waimun Chan

mun_mun123@hotmail.com

Alireza Afshari

afshari@mshdiau.ac.ir

1 Management Science Research Group, School of Informatics and Applied Mathematics, Universiti Malaysia Terengganu, Kuala Terengganu, Malaysia

2 Department of Construction Management and Industrial Engineering, Islamic Azad University, Tehran, Iran conception and computation compared to many other MCDM methods. The biggest difference between PROMETHEE and other MCDM methods is the inner relationship of PROMETHEE during the decision-making process (Murat et al. 2015). It is well adapted to the decision problems where a finite set of alternatives is to be outranked subjected to multiple conflicting criteria (Bilsel et al. 2006; Albadvi et al. 2007; Tuzkaya et al. 2010). The PROMETHEE method is based on pairwise comparisons of alternatives with respect to each criterion. According to Ulengin et al. (2001), the PROMETHEE has at least three advantages. The first advantage is its user-friendly outranking method. The second advantage is the success of PROMETHEE in applications to real-life planning problems. Another advantage of PROMETHEE lies on completeness of ranking. The PROMETHEE I and PROMETHEE II allow partial and complete ranking of alternatives, respectively. The PROMETHEE I is used to obtain partial ranking while PROMETHEE II is used for complete ranking. These two methods were developed by Brans et al. (1984, 1986).

The PROMETHEE method has been widely used in many applications in regards to its feasibility in outranking of alternatives and also its availability in multiple versions. 
Murat et al. (2015) used PROMETHEE I and PROMETHEE II to evaluate performance in schools. Tavana et al. (2013) used PROMETHEE method to identify and evaluate the alternative pipeline routes for transporting oil and gas from the Caspian basin to the world market. The PROMETHEE was applied to evaluate five possible pipeline routes. Besides, SWOT analysis was combined with the Delphi method to capture the decision makers' beliefs in which the PROMETHEE method was used to integrate these beliefs with subjective judgements. The PROMETHEE II method was used to compare five types of tires for mine machine mutually. Seven criteria have been used during the evaluation. As a consequence, the alternative-Bridgestone VMTP — was the most suitable for mine machine as the index of alternative is the highest among all alternatives (Tomic et al. 2013). Smet and Liduoh (2013) introduced a special emphasis on PROMETHEE and GAIA methods used to evaluate ten universities. More applications of PROMETHEE can be seen in a research conducted by $\mathrm{Hu}$ and Chen (2011). They proposed PROMETHEE method with concordance and discordance for financial decision-making problem regarding bankruptcy prediction. Very recently, Vasić (2018) combined the PROMETHEE and a multi-criteria analysis to participate in renewable energy sources assessment. Another combination of the PROMETHEE with two MCDM methods was applied to a research for achieving lean attributes in automotive industry (Roghanian and Alipour 2014). Nikouei et al. (2017) conducted a selection of membrane prepared from sulfonated poly and either sulfone for proton exchange membrane fuel cell based on weights of criteria using the PROMETHEE. It seems that the PROMETHEE has not yet been fully used to evaluate suppliers' selection.

Apart from direct applications of PROMETHEE, it is also good to discuss the preference functions of PROMETHEE underpinned by several types. The PROMETHEE method introduces a preference function to describe the decision maker's preference between pairs of alternatives for each criterion. In PROMETHEE method, different preference functions can be defined for criteria (Dagdeviren 2008). For example, Shi et al. (2016) used an extended $S$-shaped preference functions to express qualitative criteria such as risk preferences. There are at least six distinct types of generalized preference functions in the literature. The type I of preference function is usual criterion. It is a linear piecewise function where its range takes values of 0 to 1 and limit from the right is zero. Type II is Quasi-criterion, which is almost similar to usual criterion except its limit from the right. The other types of preference functions are type III: criterion with linear preference, type IV: level criterion, type V: criterion with linear preference and indifference area and type VI: Gaussian criteria.
It is noticed that all these functions have their own features where the differences among them are inevitable. Type VI: Gaussian criteria, for example, is nonlinear function and definitely differs from type V: criterion with linear preference and indifference area. Most of the research to date has tended to focus on combination of these six types preference functions rather than one single preference function. Therefore, in the present study, a preference of green suppliers using the PROMETHEE under type I usual criterion is proposed. However, the effect of types of preference functions of PROMETHEE on the final preferences, particularly for the case of selecting suppliers, is not immediately known. There is no general agreement about the choices of preference functions and its effect on the complete ranking. In addition, rather than the direct application of PROMETHEE under type 1 usual criterion function, comparable results are also presented to check the effect of the preference functions on the final preference for green supplier selection in a food organic supply chain.

The contributions of this paper are threefold: (1) The use of type I usual criterion of the PROMETHEE is proposed for providing a complete ranking of green suppliers. (2) Two types of preference functions are dynamically chosen to check the consistency of complete ranking in green supplier selection. (3) Finally, the supplier that optimizes the use of green criteria in supplier chain management is identified. This paper is organized as follows. Section 2 briefly reviews green supplier selection as MCDM method and related research on the MCDM methods used in green supplier selection. Section 3 presents the methodology of the research including the evaluation model. In Sect. 4, computational procedures for the case study of supplier selection and results are presented. Section 5 provides the comparative results. Finally, Sect. 6 concludes.

\section{Literature review}

The rising concern for sustainability has forced managers to incorporate environmental criteria along with economical criteria in supply chains management. In other words, green supply chain management is a set of managerial practices that integrate the environmental criteria into supply chain management. It seems like a measure to balance between economic, business and environmental issues. There are at least six main criteria in the green supply chain management such as green purchasing and green raw material procurement, green design, green product development, green manufacturing, green transportation and green process planning. Among all these criteria, the most critical criteria are green purchasing and green raw material procurement (Luthra et al. 2014). Suppliers and customers need to work mutually in order to reduce the 
environmental impact in production processes (Tseng 2011). The effective way to protect the environment is by controlling the source through green purchasing. According to Lee et al. (2009), green purchasing is the first step in the green supply chain that applies environmental criteria to the selection of services and products. Green supplier selection can be defined as an integration of environmental criteria into conventional supplier selection (Hashemi et al. 2015). In order to earn profit and achieve an effective supply chain, selection of supplier in green purchasing is a critical issue. Standard supplier selection normally includes issues such as cost of products, services provided, delivery of products, quality and quantity of products and equipment used by supplier and so on. On the other hand, green supplier selection considers some additional green criteria which are pollution control, green product and environmental management (Paulina 2014). Green supplier selection is considered as an MCDM because of the existence of multi-criteria, multiple alternatives and finite numbers of decision makers (Bali et al. 2013).

A considerable amount of literature has been published on the MCDM methods used for evaluating green supplier selection. This section provides a short literature review of green supplier selection that had been published in Scopus database from the year 2014 to 2018 . The keywords 'green supplier selection' and 'decision making' are used in this literature survey. It is summarized in Table 1.

These reviews show the importance of green criteria in selecting supplier. It can be seen that there were wide ranges of methods used in green supply chain management. So far, however, there has been little discussion about the applications of PROMETHEE to green supply chain management. To bridge the literature gap between PROMETHEE and other MCDM methods, this paper proposes an application of PROMETHEE to the case of green supplier selection problem. Different types of preference functions of PROMETHEE are used to observe its effect on the selection.

\section{Methodology}

The alternatives, criteria, decision makers and evaluation model are presented into three subsections. Preference functions used in this research are briefly explained in Sect. 3.4.

\section{Linguistic data collection}

In this research, data were collected via personal communication with a group of senior managers at an organic farm in Malaysia. In order to fit with the evaluation model, the words 'a group of senior managers' are now substituted with 'a group of decision makers' and will be used throughout this paper. The carefully selected companies offer a wide range of organic products and services to consumers through their outlets located all over Malaysia. They were asked to evaluate in terms of weight of importance to a set of criteria in green supplier selection and also weight of importance of alternatives with respect to criteria. The group of decision makers were requested to evaluate the criteria using a five-point Likert scale ranged from 'unimportant' to 'very important.' Table 2 shows the scales and their respective weight of importance.

\section{Criteria and alternatives}

In this case study, the criteria for green supplier selection are defined based on the works of Gurel et al. (2015) and Mousakhani et al. (2017). The seven criteria include cost of products $\left(C_{1}\right)$, quality of products $\left(C_{2}\right)$, service provided $\left(C_{3}\right)$, capable of delivering on time $\left(C_{4}\right)$, technology level $\left(C_{5}\right)$, environmental management systems $\left(C_{6}\right)$ and green packaging $\left(C_{7}\right)$. Four suppliers denoted by $A_{1}, A_{2}, A_{3}$ and $A_{4}$ were investigated in this study. The supplier $A_{1}$ is MVG Food Marketing Sdn Bhd. They supplied vegan organic frozen food. The wide variety of products is frozen dumpling and frozen meal box like lemongrass chicken rice. Supplier $A_{2}$ is CF org Noodle Sdn Bhd, which is a noodle manufacturer company. The products they offer are whole wheat noodle, spinach noodle and spirulina stick noodle. The supplier $A_{3}$ is Hexa Food Sdn Bhd which is a spice, herb and seasoning manufacturer. They sell a variety of ground spices and seasoning to use in preparing dishes. Supplier $A_{4}$ is SCS Food Manufacturing Sdn Bhd, which is a sugar and salt manufacturer. They supply variety of salts such as organic salt, fine salt and coarse salt.

\section{Evaluation model}

The PROMETHEE method begins with an evaluation of alternatives with respect to the criteria. These evaluations essentially need numerical data where their implementation needs information on the relative importance of the criteria and also information on the decision maker's preference functions. The information is obtained when the decision makers compared the contribution of the alternatives with respect to each criterion. The computational procedures of PROMETHEE need several steps, and this paper has summarized seven steps based on the works of Polat (2015), Geldermann et al. (2000), Behzadian et al. (2010) and Brans et al. (1986).

Step 1 Determine the criteria $(j=1, \ldots, k)$ and the set of possible alternatives in a decision problem. 
Table 1 Review of MCDM methods used for green suppliers research

\begin{tabular}{|c|c|c|c|}
\hline Author & Objective & MCDM method & $\begin{array}{l}\text { Economic criteria and green } \\
\text { criteria }\end{array}$ \\
\hline $\begin{array}{l}\text { Qin et al. } \\
\text { (2017) }\end{array}$ & To select the best supplier & $\begin{array}{l}\text { TODIM, interval type } 2 \text { fuzzy set, } \\
\text { sensitivity analysis }\end{array}$ & $\begin{array}{l}\text { 1. Green product innovation } \\
\text { 2. Green image } \\
\text { 3. Use of environmentally friendly } \\
\text { technology } \\
\text { 4. Resource consumption } \\
\text { 5. Green competencies } \\
\text { 6. Environment } \\
\text { management } \\
\text { 7. Quality management } \\
\text { 8. Total product life cycle } \\
\text { cost } \\
\text { 9. Pollution production } \\
\text { 10. Staff environmental } \\
\text { training }\end{array}$ \\
\hline $\begin{array}{l}\text { Guo et al. } \\
\text { (2017) }\end{array}$ & To evaluate and select the best material supplier & Fuzzy MCDM & $\begin{array}{l}\text { 1. Quality } \\
\text { 2. Cost } \\
\text { 3. Delivery } \\
\text { 4. Technology } \\
\text { 5. Service environmental } \\
\text { competency }\end{array}$ \\
\hline $\begin{array}{l}\text { Galankashi } \\
\text { et al. (2015) }\end{array}$ & $\begin{array}{l}\text { To rank the most relevant criteria in green supplier } \\
\text { selection problem. }\end{array}$ & $\begin{array}{l}\text { Nominal group technique and a } \\
\text { fuzzy analytical network process } \\
\text { (FANP) }\end{array}$ & $\begin{array}{l}\text { 1. Price } \\
\text { 2. Quality } \\
\text { 3. Reputation } \\
\text { 4. Service and delivery } \\
\text { 5. Distance } \\
\text { 6. Use of green materials, } \\
\text { 7. Air emission level } \\
\text { 8. Waste level } \\
\text { 9. Energy efficiency } \\
\text { 10. Green design capability }\end{array}$ \\
\hline $\begin{array}{l}\text { Kannan et al. } \\
\text { (2014a) }\end{array}$ & $\begin{array}{l}\text { To select the best green supplier for Singapore- } \\
\text { based plastic manufacturing company }\end{array}$ & The fuzzy axiomatic design model & $\begin{array}{l}\text { 1. Quality } \\
\text { 2. Price } \\
\text { 3. Capability of supplier/delivery } \\
\text { 4. Services } \\
\text { 5. Environment protection/ } \\
\text { environment management } \\
\text { 6. Corporate social responsibility } \\
\text { 7. Pollution control } \\
\text { 8. Green product } \\
\text { 9. Green image } \\
\text { 10. Green innovation } \\
\text { 11. Hazardous substance } \\
\text { management }\end{array}$ \\
\hline $\begin{array}{l}\text { Govindan and } \\
\text { Sivakumar } \\
\text { (2016) }\end{array}$ & $\begin{array}{l}\text { To select the supplier that engages in diminishing } \\
\text { the greenhouse gases (GHG) emissions }\end{array}$ & $\begin{array}{l}\text { Fuzzy TOPSIS } \\
\text { single-objective linear } \\
\text { programming }\end{array}$ & $\begin{array}{l}\text { 1. Cost } \\
\text { 2. Quality } \\
\text { 3. Delivery } \\
\text { 4. Recycle capability } \\
\text { 5. CHG emissions }\end{array}$ \\
\hline
\end{tabular}


Table 1 (continued)

\begin{tabular}{|c|c|c|c|}
\hline Author & Objective & MCDM method & $\begin{array}{l}\text { Economic criteria and green } \\
\text { criteria }\end{array}$ \\
\hline $\begin{array}{l}\text { Kannan etal. } \\
\text { (2014b) }\end{array}$ & $\begin{array}{l}\text { To select the green supplier for a Brazilian } \\
\text { electronics company }\end{array}$ & $\begin{array}{l}\text { The fuzzy TOPSIS Spearman rank } \\
\text { correlation coefficient, } \\
\text { sensitivity analysis }\end{array}$ & $\begin{array}{l}\text { 1. Commitment of senior } \\
\text { management } \\
\text { 2. Product designs } \\
\text { 3. Reduce, reuse, recycle or } \\
\text { reclaim } \\
\text { materials, components, or energy } \\
\text { 4. Compliance with legal } \\
\text { environmental requirements and } \\
\text { auditing programs } \\
\text { 5. Product designs that avoid or } \\
\text { reduce toxic or hazardous } \\
\text { material use }\end{array}$ \\
\hline $\begin{array}{l}\text { Banaeian et al. } \\
\text { (2018). }\end{array}$ & $\begin{array}{l}\text { To complete a green supplier evaluation and } \\
\text { selection study for an actual company from the } \\
\text { agri-food industry }\end{array}$ & $\begin{array}{l}\text { Fuzzy sets, TOPSIS, VIKOR and } \\
\text { GRA }\end{array}$ & $\begin{array}{l}\text { 1. Service level } \\
\text { 2. Quality } \\
\text { 3. Price } \\
\text { 4. Environmental management } \\
\text { system }\end{array}$ \\
\hline $\begin{array}{l}\text { Mousakhani } \\
\text { et al. (2017) }\end{array}$ & $\begin{array}{l}\text { To propose solution for green supplier selection } \\
\text { problems. }\end{array}$ & $\begin{array}{l}\text { Interval type } 2 \text { fuzzy TOPSIS, } \\
\text { sensitivity analysis }\end{array}$ & $\begin{array}{l}\text { 1. Cost } \\
\text { 2. Quality } \\
\text { 3. Delivery } \\
\text { 4. Technology } \\
\text { 5. Environmental competency } \\
\text { 6. Organization } \\
\text { 7. Green image }\end{array}$ \\
\hline $\begin{array}{l}\text { Pang et al. } \\
\text { (2017) }\end{array}$ & To select the suppliers & $\begin{array}{l}\text { Fuzzy set theory and grey } \\
\text { relational analysis }\end{array}$ & $\begin{array}{l}\text { 1. Enterprise low-carbon } \\
\text { qualification } \\
\text { 2. Low-carbon production and } \\
\text { service } \\
\text { 3. Low-carbon business operation } \\
\text { 4. Low-carbon innovation }\end{array}$ \\
\hline $\begin{array}{l}\text { Mohammadi } \\
\text { et al. (2017) }\end{array}$ & To select the suppliers & $\begin{array}{l}\text { Fuzzy preference relation, interval } \\
\text { type } 2 \text { fuzzy sets }\end{array}$ & $\begin{array}{l}\text { 1. Product cost } \\
\text { 2. Product quality } \\
\text { 3. Environmental performance } \\
\text { 4. Services }\end{array}$ \\
\hline
\end{tabular}

Table 2 Five-point Likert scale and its description

\begin{tabular}{ll}
\hline Scale & Weight of importance \\
\hline 1 & Unimportant \\
2 & Less important \\
3 & Moderately important \\
4 & Important \\
5 & Very important \\
\hline
\end{tabular}

Step 2 Determine the weight $w_{j}$ of the criteria. It shows the relative importance of each of the criteria and notes that $\sum_{j=1}^{k} w_{j}=1$

Step 3 Normalize the decision matrix to range $0-1$ by using

$\begin{aligned} R_{i j} & =\frac{\left\lfloor X_{i j}-\min \left(\mathrm{X}_{\mathrm{ij}}\right)\right\rfloor}{\left[\max \left(X_{i j}\right)-\min \left(X_{i j}\right)\right]} \\ & (i=1,2 \ldots, n \text { and } j=1,2, \ldots, m),\end{aligned}$

where $X_{i j}$ is evaluation values provided by decision makers $i=1 \ldots \ldots, n$, and numbers of criteria $j=1, \ldots, m$. 
Step 4 Determination of deviation by pairwise comparison.

$d_{j}(a, b)=g_{j}(a)-g_{j}(b)$

$d_{j}(a, b)$ denotes the difference between the evaluations of $a$ and $b$ on each criterion.

Step 5 Define the preference function $P_{j}(a, b)=F_{j}\left[d_{j}(a\right.$, b)],

where $P_{j}(a, b)$ represent the function of the difference between the evaluations of alternative $a$ regarding alternative $b$ on each criterion into a degree ranging from 0 to 1 . The smaller number of the functions denotes the indifference of the decision maker. On the contrary, the closer to 1 indicates greater the preference.

Step 6 Determine the multi-criteria preference index.

$\pi(a, b)=\sum_{j=1}^{k} P(a, b) w_{j}$

where $w_{j}>0$ are the weights associated with each criterion. The symbol $\pi(a, b)$ shows that the degree of $a$ is preferred to $b$ over all the criteria.

$\pi(a, b) \approx 0$ implies a weak preference of $a$ over $b$.

$\pi(a, b) \approx 1$ implies a strong preference of $a$ over $b$.

Step 7 Obtain the preference order

In this step, ranking can be made either partially or completely. Partial ranking can be obtained using PROMETHEE I, and in case complete ranking is needed, then the computation must proceed to one more step in PROMETHEE II.

(a) Ranking the actions by partial ranking (PROMETHEE I).

$$
\begin{aligned}
\phi^{+}(a) & =\frac{1}{n-1} \sum_{x \in A} \pi(a, x) \text { and } \phi^{-}(a) \\
& =\frac{1}{n-1} \sum_{x \in A} \pi(a, x) .
\end{aligned}
$$

$\phi^{+}(a)$ represents positive outranking flow or is known as leaving flow (how $a$ dominates all the other alternatives), and $\phi^{-}(a)$ represents the negative outranking flow or is known as entering flow (how $a$ is dominated by all the other alternatives).

The alternative with a higher value of $\phi^{+}(a)$ and the lower value of $\phi^{-}(a)$ is the best alternative. The preference relation and partial ranking are derived as follows:

$$
\begin{aligned}
& a P^{+} b: \begin{cases}\text { Piff }^{+}(a) \succ \phi^{+}(b), & \forall a, b \in A \\
\text { Iiff } \phi^{+}(a)=\phi^{+}(b), & \forall a, b \in A\end{cases} \\
& a P^{-} b: \begin{cases}\operatorname{Piff}^{-}(a) \prec \phi^{-}(b), & \forall a, b \in A \\
\text { Iiff } \phi^{-}(a) \succ \phi^{-}(b), & \forall a, b \in A\end{cases}
\end{aligned}
$$

However, not all alternatives are comparable. Thus, we need to calculate the net outranking flow in the following step.

b. Ranking the actions by a complete ranking (PROMETHEE II).

The complete ranking of alternatives can avoid incomparability.

$\phi(a)=\phi^{+}(a)-\phi^{-}(a)$,

where $\phi(a)$ denotes the net outranking flow for each alternative. The preference relations are as follows:

$a$ outranks of $b\left(a P^{(I I)} b\right) \quad$ iff $\phi(a) \succ \phi(b), \quad \forall a, b \in A$

$a$ indifferent of $b a P^{(I I)} b \quad$ iff $\phi(a)=\phi(b), \quad \forall a, b \in A$

Thus, all the alternatives are able to be compared based on the values of $\phi(a)$. The highest values of $\phi(a)$ denote the most preferred alternative.

In these series of computational procedures, most of the steps are fixed except Step 5. In this step, it is an arbitrary where the choice of preference functions depends very much on the characteristics of criteria and also the preference of decision makers. Attention is paid to the choice of types of preference functions as it may affect the final net outranking values.

\section{Preference functions}

The implementation of the PROMETHEE method requires preference functions. Preference function of PROMETHEE is a function used to define deviations between alternatives for each criterion. In this paper, the definitions of preference functions are presented to fulfill the requirement of PROMETHEE algorithm that will be implemented to a case study (Tuzkaya et al. 2010; Ozgen et al. 2011; Brans and Vincle 1985). With reference to Step 5, in Subsect. 3.3, three preference functions are employed. They are defined as follows.

Definition 1 Type I: Usual criteria function is defined as

$p(x)= \begin{cases}0, & \text { for } x \leq 0 \\ 1, & \text { for } x>0\end{cases}$

where $x$ represents the deviation between two alternatives.

In type 1 , indifference only occurs when $f(a)=f(b)$. It is used when the decision makers cannot allocate importance for the differences between criteria values and only seem to know the formula 'the more the better.'

Definition 2 Type III: Criterion with linear preference function is defined as 
$p(x)= \begin{cases}0, & x<0 \\ \frac{x}{m}, & 0 \leq x \geq m \\ 1, & x>m\end{cases}$

The intensity of preference increases linearly and becomes strict on point $m$. Parameter $m$ is arbitrary and needs to be defined.

Definition 3 Type IV: Level criterion function is defined as

$p(x)= \begin{cases}0, & \text { for } x \leq q \\ \frac{1}{2}, & \text { for } q<x \leq q+p \\ 1, & \text { for } x>q+p\end{cases}$

Indifference on the interval $[-q, q]$. For type IV, it is always used for quantitative criteria.

\section{Proposed selection framework and implementation}

The framework applied to green supplier selection is presented in Fig. 1.
The framework includes the goal of selection problem, the economical and environmental criteria, the suppliers and also the expected results of partial ranking and net outranking.

The implementation of PROMETHEE to the case is made by identifying the decision makers, green criteria and the suppliers. In personal communication, a group of five managers $\left(D_{1}, D_{2}, D_{3}, D_{4}, D_{5}\right)$ was requested to rank and evaluate four suppliers $\left(A_{1}, A_{2}, A_{3}, A_{4}\right)$ based on the seven criteria $\left(C_{1}, C_{2}, C_{3}, C_{4}, C_{5}, C_{6}, C_{7}\right)$.

Data that were collected are shown in Table 3.

Information in Table 3 and the computational procedures using the usual criterion preference functions (see Sect. 3.3) are computed according to the following steps.

Step 1 Identify the criteria and suppliers

Criteria: cost $\left(C_{1}\right)$, quality $\left(C_{2}\right)$, services $\left(C_{3}\right)$, delivering on time $\left(C_{4}\right)$, technology level $\left(C_{5}\right)$, environmental management systems $\left(C_{6}\right)$, green packaging $\left(C_{7}\right)$.

Suppliers: supplier $A_{1}$, supplier $A_{2}$, supplier $A_{3}$, supplier $A_{4}$.

To understand the relationship between suppliers and criteria, the analysis of GAIA (Graphical Analysis for Interactive Assistance) is made. With a representation

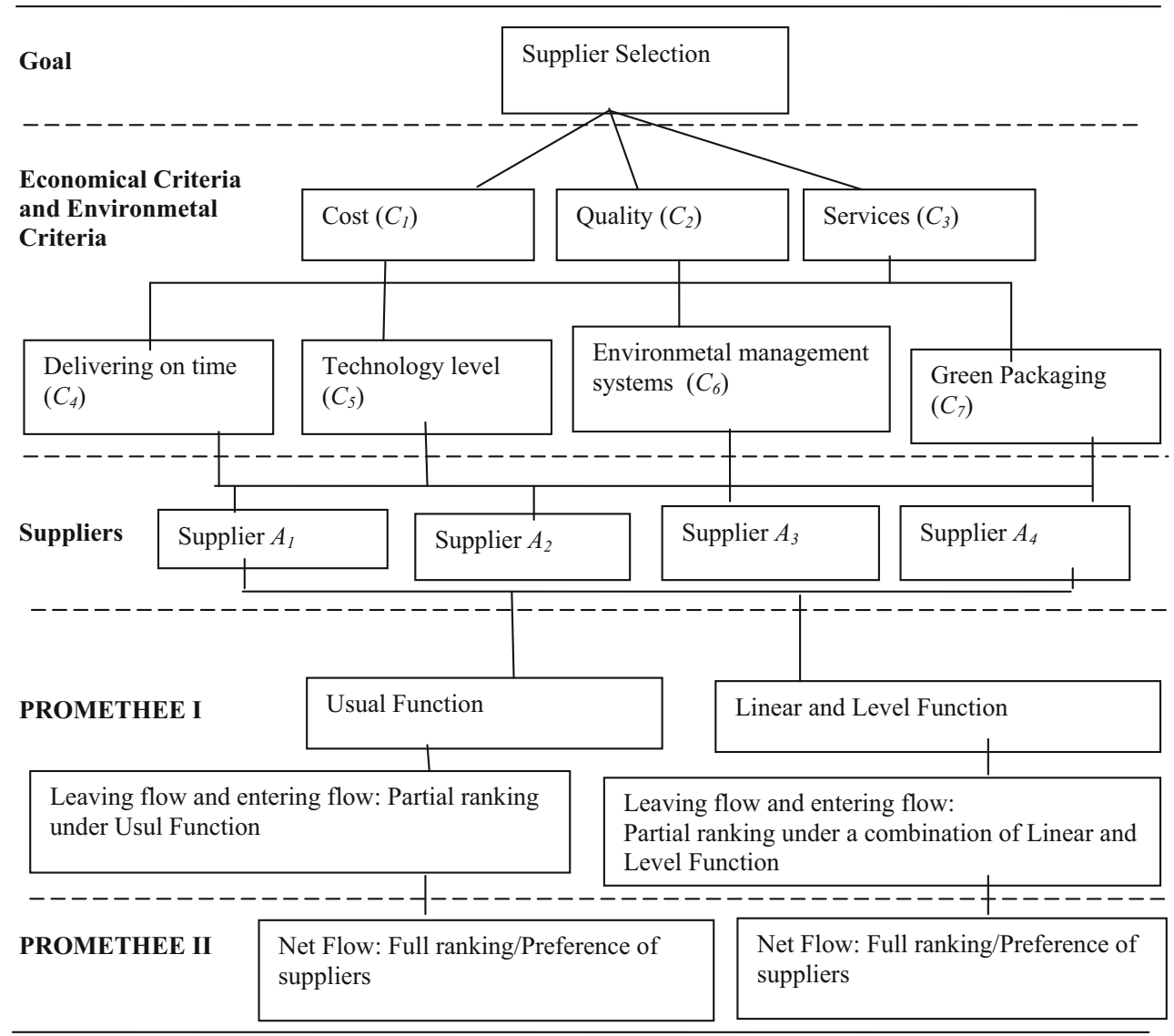

Fig. 1 Framework for supplier selection 
Table 3 Performance rating of the suppliers

\begin{tabular}{|c|c|c|c|c|c|c|}
\hline Criteria & Managers & $D_{1}$ & $D_{2}$ & $D_{3}$ & $D_{4}$ & $D_{5}$ \\
\hline Cost & Supplier $A_{1}$ & 4 & 4 & 5 & 4 & 4 \\
\hline \multirow[t]{3}{*}{$C_{1}$} & Supplier $A_{2}$ & 2 & 3 & 3 & 2 & 3 \\
\hline & Supplier $A_{3}$ & 3 & 3 & 4 & 2 & 3 \\
\hline & Supplier $A_{4}$ & 3 & 3 & 3 & 3 & 3 \\
\hline Quality & Supplier $A_{1}$ & 4 & 3 & 3 & 4 & 3 \\
\hline \multirow[t]{3}{*}{$C_{2}$} & Supplier $A_{2}$ & 3 & 2 & 2 & 3 & 3 \\
\hline & Supplier $A_{3}$ & 3 & 3 & 2 & 3 & 2 \\
\hline & Supplier $A_{4}$ & 3 & 3 & 2 & 3 & 3 \\
\hline Services & Supplier $A_{1}$ & 4 & 4 & 5 & 4 & 5 \\
\hline \multirow[t]{3}{*}{$C_{3}$} & Supplier $A_{2}$ & 4 & 3 & 4 & 4 & 5 \\
\hline & Supplier $A_{3}$ & 3 & 4 & 3 & 3 & 4 \\
\hline & Supplier $A_{4}$ & 4 & 4 & 3 & 3 & 4 \\
\hline Delivering on time & Supplier $A_{1}$ & 5 & 4 & 3 & 3 & 4 \\
\hline \multirow[t]{3}{*}{$C_{4}$} & Supplier $A_{2}$ & 3 & 3 & 3 & 3 & 3 \\
\hline & Supplier $A_{3}$ & 4 & 4 & 3 & 2 & 3 \\
\hline & Supplier $A_{4}$ & 4 & 4 & 3 & 2 & 4 \\
\hline Technology level & Supplier $A_{1}$ & 3 & 5 & 3 & 5 & 5 \\
\hline \multirow[t]{3}{*}{$C_{5}$} & Supplier $A_{2}$ & 3 & 3 & 2 & 3 & 4 \\
\hline & Supplier $A_{3}$ & 3 & 3 & 3 & 4 & 4 \\
\hline & Supplier $A_{4}$ & 3 & 3 & 4 & 4 & 4 \\
\hline Environmental management systems & Supplier $A_{1}$ & 3 & 4 & 4 & 3 & 4 \\
\hline \multirow[t]{3}{*}{$C_{6}$} & Supplier $A_{2}$ & 3 & 2 & 4 & 3 & 3 \\
\hline & Supplier $A_{3}$ & 3 & 3 & 3 & 3 & 4 \\
\hline & Supplier $A_{4}$ & 3 & 2 & 3 & 3 & 4 \\
\hline Green packaging & Supplier $A_{1}$ & 3 & 3 & 3 & 4 & 4 \\
\hline \multirow[t]{3}{*}{$\mathrm{C}_{7}$} & Supplier $A_{2}$ & 3 & 3 & 3 & 3 & 3 \\
\hline & Supplier $A_{3}$ & 3 & 4 & 5 & 3 & 4 \\
\hline & Supplier $A_{4}$ & 3 & 3 & 3 & 3 & 4 \\
\hline
\end{tabular}

value of $97 \%$, the relationship between suppliers and criteria is depicted in Fig. 2.

It can be seen that there are two groups of criteria, which can be identified as $\{C 6, C 4, C 1, C 5, C 7\}$ and $\{C 2, C 3\}$. These two sets seem to be independent from each other, and therefore, there is no strong conflict between the criteria

Step 2 Compute criteria weight.

Evaluations provided by the decision makers need to be normalized in the range $0-1$ and compute the fraction based on each criterion. Using the normalization in $\mathrm{Eq}$ (1) and fraction, the normalized data given by each decision maker are summarized in Table 4.

Then, aggregate the weight of each criterion using arithmetic mean. Table 5 presents the criteria and their respective weights.

Step 3 Normalize and aggregate the rating of suppliers.

The ratings of suppliers are averaged to aggregate and normalize them to $0-1$ scale. The evaluations of four suppliers corresponding to all the criteria are displayed in Table 6.

Step 4 Determination of deviation by pairwise comparison.

This step involves the calculation of the differences in criteria values of $A_{1}$ with respect to other suppliers. The deviations are obtained using Eq (2). The summary of deviations is shown in Table 7.

Step 5 Selection of preference function.

The implementation of the PROMETHEE method requires a preference function. Preference function of PROMETHEE is a function used to define deviations between alternatives for each criteria. The usual criterion preference function (see Eq 6) is employed in this step. Table 8 shows the deviations using usual function.

Step 6 Calculate the preference index.

Calculation of the preference index of each supplier takes into account the criteria weight. It is also a value to show the degree of preference of a supplier over another 
Fig. 2 GAIA visual analysis



Table 4 Normalized data for each criterion

\begin{tabular}{llllll}
\hline Criteria & $D_{1}$ & $D_{2}$ & $D_{3}$ & $D_{4}$ & $D_{5}$ \\
\hline$C_{1}$ & 0.1667 & 0.1905 & 0.1818 & 0.1905 & 0.20 \\
$C_{2}$ & 0.2222 & 0.1905 & 0.1818 & 0.1905 & 0.15 \\
$C_{3}$ & 0.1111 & 0.1429 & 0.1818 & 0.0952 & 0.10 \\
$C_{4}$ & 0.1667 & 0.1429 & 0.1818 & 0.1429 & 0.20 \\
$C_{5}$ & 0.1111 & 0.0952 & 0.0909 & 0.0952 & 0.15 \\
$C_{6}$ & 0.1111 & 0.0952 & 0.0909 & 0.1429 & 0.10 \\
$C_{7}$ & 0.1111 & 0.1429 & 0.0909 & 0.1429 & 0.10 \\
\hline
\end{tabular}

Table 5 Average weights of criteria

\begin{tabular}{ll}
\hline Criteria & Average weight \\
\hline$C_{1}$ & 0.1859 \\
$C_{2}$ & 0.1870 \\
$C_{3}$ & 0.1262 \\
$C_{4}$ & 0.1669 \\
$C_{5}$ & 0.1085 \\
$C_{6}$ & 0.1080 \\
$C_{7}$ & 0.1176 \\
\hline
\end{tabular}

Table 6 Evaluation of supplier with respect to criteria

\begin{tabular}{lllll}
\hline Criteria & Supplier $A_{1}$ & Supplier $A_{2}$ & Supplier $A_{3}$ & Supplier $A_{4}$ \\
\hline$C_{1}$ & 0.8 & 0.4 & 0.5 & 0.5 \\
$C_{2}$ & 0.6 & 0.4 & 0.4 & 0.45 \\
$C_{3}$ & 0.85 & 0.75 & 0.6 & 0.65 \\
$C_{4}$ & 0.7 & 0.5 & 0.55 & 0.6 \\
$C_{5}$ & 0.8 & 0.5 & 0.6 & 0.65 \\
$C_{6}$ & 0.65 & 0.5 & 0.55 & 0.5 \\
$C_{7}$ & 0.6 & 0.5 & 0.7 & 0.55 \\
\hline
\end{tabular}

supplier. The index is calculated using Eq (3). The preference index is presented in Table 9.

Step 7 Determine the positive and negative outranking flows of each supplier (PROMETHEE I partial ranking).

(a) Leaving flow and entering flow of suppliers

Positive outranking flow (leaving flow) shows the degree of the supplier dominated other suppliers. In contrast, negative outranking flow (entering flow) shows the degree of the supplier dominated by other suppliers. Equation (4) is used to calculate these two 
Table 7 Deviations of any two potential suppliers with respect to criteria $C_{j}$

\begin{tabular}{lccccccc}
\hline & $C_{1}$ & \multicolumn{1}{c}{$C_{2}$} & $C_{3}$ & $C_{4}$ & $C_{5}$ & $C_{6}$ & \multicolumn{1}{c}{$C_{7}$} \\
\hline$A_{1} A_{2}$ & 0.4 & 0.2 & 0.1 & 0.2 & 0.3 & 0.15 & 0.1 \\
$A_{1} A_{3}$ & 0.3 & 0.2 & 0.25 & 0.15 & 0.2 & 0.1 & -0.1 \\
$A_{1} A_{4}$ & 0.3 & 0.15 & 0.2 & 0.1 & 0.15 & 0.15 & 0.05 \\
$A_{2} A_{1}$ & -0.4 & -0.2 & -0.1 & -0.2 & -0.3 & -0.15 & -0.1 \\
$A_{2} A_{3}$ & -0.1 & 0 & 0.15 & -0.05 & -0.1 & -0.05 & -0.2 \\
$A_{2} A_{4}$ & -0.1 & -0.05 & 0.1 & -0.1 & -0.15 & 0 & -0.05 \\
$A_{3} A_{1}$ & -0.3 & -0.2 & -0.25 & -0.15 & -0.2 & -0.1 & 0.1 \\
$A_{3} A_{2}$ & 0.1 & 0 & -0.15 & 0.05 & 0.1 & 0.05 & 0.2 \\
$A_{3} A_{4}$ & 0 & -0.05 & -0.05 & -0.05 & -0.05 & 0.05 & 0.15 \\
$A_{4} A_{1}$ & -0.3 & -0.15 & -0.2 & -0.1 & -0.15 & -0.15 & -0.05 \\
$A_{4} A_{2}$ & 0.1 & 0.05 & -0.1 & 0.1 & 0.15 & 0 & 0.05 \\
$A_{4} A_{3}$ & 0 & 0.05 & 0.05 & 0.05 & 0.05 & -0.05 & -0.15 \\
\hline
\end{tabular}

Table 8 Preference function-usual function

\begin{tabular}{llllllll}
\hline & $C_{1}$ & $C_{2}$ & $C_{3}$ & $C_{4}$ & $C_{5}$ & $C_{6}$ & $C_{7}$ \\
\hline$A_{1} A_{2}$ & 1 & 1 & 1 & 1 & 1 & 1 & 1 \\
$A_{1} A_{3}$ & 1 & 1 & 1 & 1 & 1 & 1 & 0 \\
$A_{1} A_{4}$ & 1 & 1 & 1 & 1 & 1 & 1 & 1 \\
$A_{2} A_{1}$ & 0 & 0 & 0 & 0 & 0 & 0 & 0 \\
$A_{2} A_{3}$ & 0 & 0 & 1 & 0 & 0 & 0 & 0 \\
$A_{2} A_{4}$ & 0 & 0 & 1 & 0 & 0 & 0 & 0 \\
$A_{3} A_{1}$ & 0 & 0 & 0 & 0 & 0 & 0 & 1 \\
$A_{3} A_{2}$ & 1 & 0 & 0 & 1 & 1 & 1 & 1 \\
$A_{3} A_{4}$ & 0 & 0 & 0 & 0 & 0 & 1 & 1 \\
$A_{4} A_{1}$ & 0 & 0 & 0 & 0 & 0 & 0 & 0 \\
$A_{4} A_{2}$ & 1 & 1 & 0 & 1 & 1 & 0 & 1 \\
$A_{4} A_{3}$ & 0 & 1 & 1 & 1 & 1 & 0 & 0 \\
\hline
\end{tabular}

Table 9 Preference index value

\begin{tabular}{lllll}
\hline Suppliers & Supplier $A_{1}$ & Supplier $A_{2}$ & Supplier $A_{3}$ & Supplier $A_{4}$ \\
\hline Supplier $A_{1}$ & & 1.0001 & 0.8825 & 1.0001 \\
Supplier $A_{2}$ & 0 & & 0.1262 & 0.1262 \\
Supplier $A_{3}$ & 0.1176 & 0.6869 & & 0.2256 \\
Supplier $A_{4}$ & 0 & 0.7659 & 0.5886 & \\
\hline
\end{tabular}

flows. Leaving flow and entering flow of suppliers are shown in Table 10.

(b) Determine the net outranking flow (PROMETHEE II) for each supplier.

Net flow values are calculated to avoid incomparability. Equation (5) is used to complete the calculation of net outranking flow. It is presented in Table 11.
Table 10 PROMETHEE I flow

\begin{tabular}{lll}
\hline Suppliers & $\phi^{+}(a)$ & $\phi^{-}(a)$ \\
\hline Supplier $A_{1}$ & 0.9609 & 0.0392 \\
Supplier $A_{2}$ & 0.084133 & 0.817633 \\
Supplier $A_{3}$ & 0.343367 & 0.532433 \\
Supplier $A_{4}$ & 0.4515 & 0.450633
\end{tabular}

Table 11 Net flow value of suppliers

\begin{tabular}{lc}
\hline Suppliers & Net flow, $\phi(a)$ \\
\hline Supplier $A_{1}$ & 0.9217 \\
Supplier $A_{2}$ & -0.7335 \\
Supplier $A_{3}$ & -0.189067 \\
Supplier $A_{4}$ & 0.000867 \\
\hline
\end{tabular}

The ranking of suppliers is arranged in descending order of net flow value. The best supplier is the one having the highest net flow value, $\phi(a)$. By using PROMETHEE II (complete ranking) method, supplier $A_{1} \_$MVG Food Marketing Sdn Bhd-is selected as the best alternative.

The results of PROMETHEE I and PROMETHEE II are presented in Table 10 and Table 11, respectively. These results could be corroborated by drawing a PROMETHEE Diamond chart as this chart displays the results of PROMETHEE I and PROMETHEE II simultaneously. Figure 3 displays the positions of alternatives (PROMETHEE IIcomplete ranking) and also the positive and negative outranking flows values (PROMETHEE I partial ranking) of alternatives.

It can be seen that alternative $A_{1}$ is ranked as the first preference followed by $A_{4}$. The ranking order of preference of suppliers is obtained as $A_{1} \succ A_{4} \succ A_{3} \succ A_{2}$, where ' $\succ$ ' shows 'more preferred than.' It can be concluded that 
Fig. 3 PROMETHEE diamond

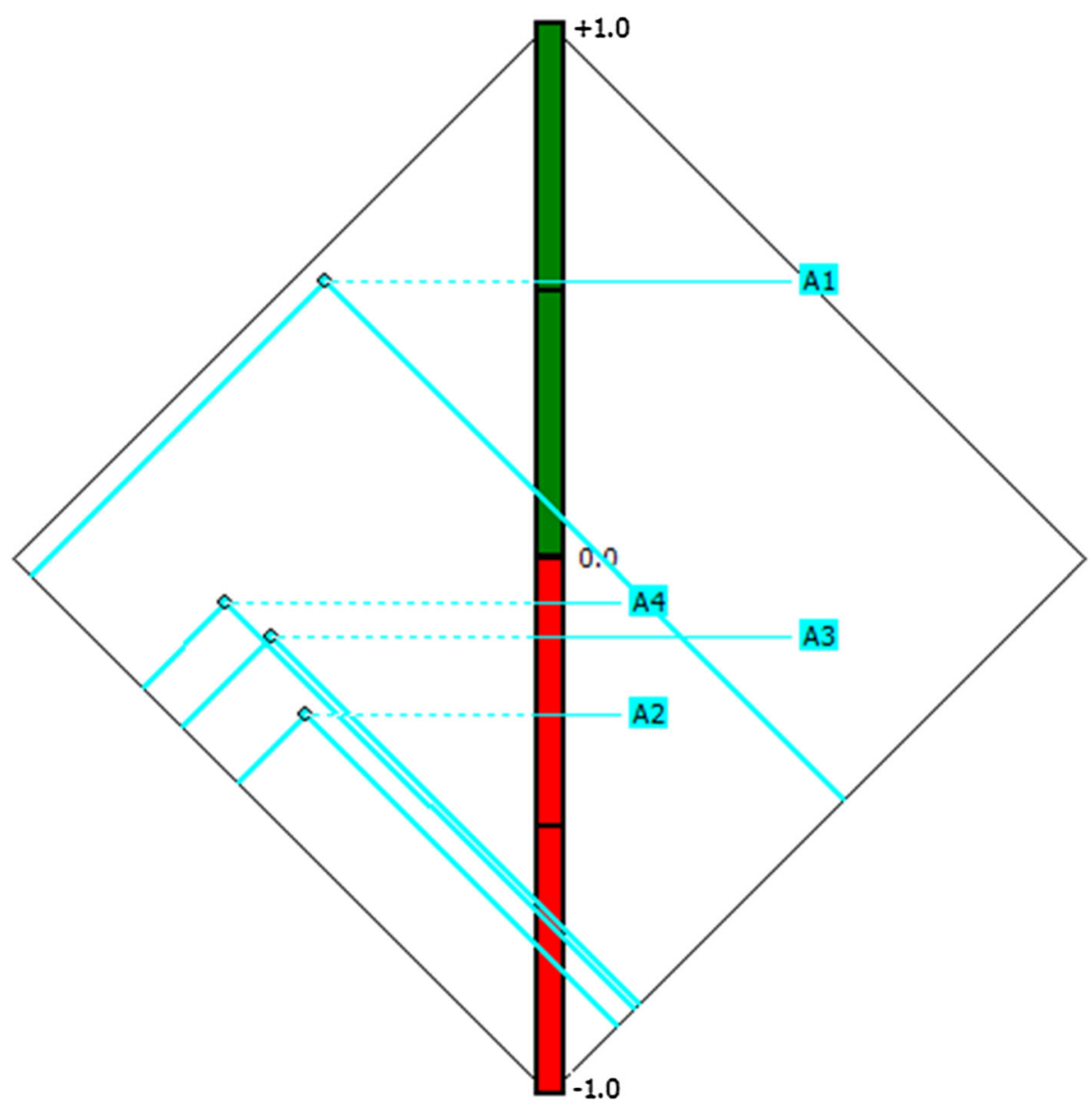

MVG Food Marketing Sdn Bhd is the most preferred supplier.

It is often difficult to get a robust result due to the variability in relative importance of a given criterion. In response to this issue, an interactive tool called walking weights is used to check the sensitivity of the result. For example, the relative importance of the criterion $\mathrm{C}_{2}$ is increased by 33\%; thus, new result is shown in Fig. 4.

It is noticed that the result does not have an impact on the first-ranked alternative. However, a slight inconsistency in ranking can be seen for other three alternatives. The results obtained are further discussed in Sect. 5.

Fig. 4 Walking weights
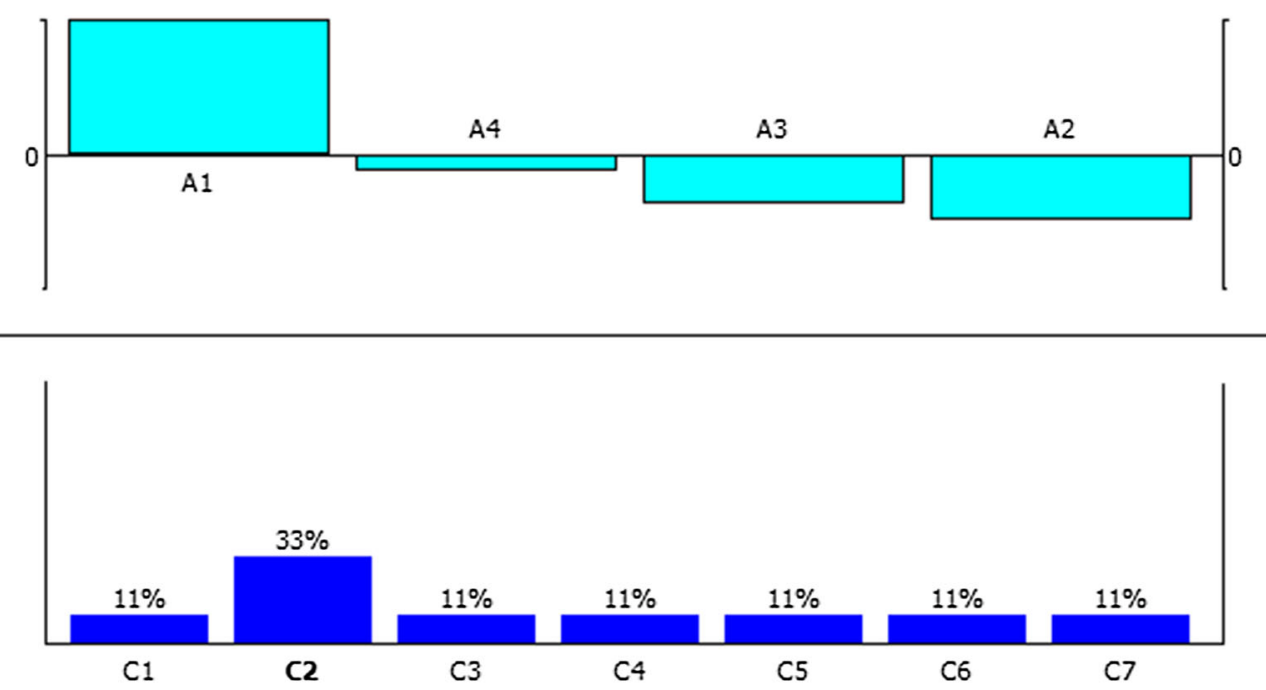


\section{Comparative results}

In PROMETHEE, it is possible to choose a different preference function for each criterion. Differently from the preference function used in Sect. 4, linear preference function with linear preference and indifference area (type V) and level preference function (type IV) are chosen for the green supplier selection problem (Tuzkaya et al. 2010; Ozgen et al. 2011; Brans and Vincke 1985). Both functions are chosen based on the nature of criteria. The PROMETHEE with linear and level function method is assumed to be tailored to the nature of the criteria. For instance, linear preference function was chosen as one of the functions because it is best suited for quantitative criteria such as criterion $\mathrm{C}_{1}$ (cost). However, level preference function is best suited for qualitative criteria such as criterion $\mathrm{C}_{2}$ (quality of products). In addition, the level function works well in small numbers of different levels, such as five-point measure scale.

To begin with the computations, Step 1 to Step 4 in Sect. 4.3 are iterated. For the purpose of comparative analysis, Step 4 is continued as follows.

Step 5 Selection of preference function.

In this step, linear and level functions are chosen corresponding to the criteria used in this study. Linear function and level function are defined in Eqs (7) and (8), respectively.

Both of the linear and level functions consist of indifference and preference thresholds. The indifference threshold represents the largest value of $q$ which is there is no preference for suppliers over another whereas the preference threshold represents the smallest value of $p$ which is sufficient to generate a full preference. In this case study, indifference threshold and preference threshold are set as 0.05 and 0.1 , respectively. Table 12 shows the criteria and their respective preference function.

Deviations between alternatives are translated into the domains of preference functions. It is shown in Table 13.

Step 6 Calculate the preference index value.

Table 12 Type of preference function corresponding to criteria

\begin{tabular}{ll}
\hline Criteria & Type of preference function \\
\hline$C_{1}$ & Linear \\
$C_{2}$ & Level \\
$C_{3}$ & Level \\
$C_{4}$ & Level \\
$C_{5}$ & Level \\
$C_{6}$ & Level \\
$C_{7}$ & Level \\
\hline
\end{tabular}

Table 13 Preference function-linear and level function

\begin{tabular}{llllllll}
\hline & $C_{1}$ & $C_{2}$ & $C_{3}$ & $C_{4}$ & $C_{5}$ & $C_{6}$ & $C_{7}$ \\
\hline$A_{1}, A_{2}$ & 1 & 1 & 0.5 & 1 & 1 & 1 & 0.5 \\
$A_{1}, A_{3}$ & 1 & 1 & 1 & 1 & 1 & 0.5 & 0 \\
$A_{1}, A_{4}$ & 1 & 1 & 1 & 0.5 & 1 & 1 & 0 \\
$A_{2}, A_{1}$ & 0 & 0 & 0 & 0 & 0 & 0 & 0 \\
$A_{2}, A_{3}$ & 0 & 0 & 1 & 0 & 0 & 0 & 0 \\
$A_{2}, A_{4}$ & 0 & 0 & 0.5 & 0 & 0 & 0 & 0 \\
$A_{3}, A_{1}$ & 0 & 0 & 0 & 0 & 0 & 0 & 0.5 \\
$A_{3}, A_{2}$ & 1 & 0 & 0 & 0 & 0.5 & 0 & 1 \\
$A_{3}, A_{4}$ & 0 & 0 & 0 & 0 & 0 & 0 & 1 \\
$A_{4}, A_{1}$ & 0 & 0 & 0 & 0 & 0 & 0 & 0 \\
$A_{4}, A_{2}$ & 1 & 0 & 0 & 0.5 & 1 & 0 & 0 \\
$A_{4}, A_{3}$ & 0 & 0 & 0 & 0 & 0 & 0 & 0 \\
\hline
\end{tabular}

Preference index values are obtained using Eq (3), and the results are presented in Table 14.

Step 7 Determine the positive and negative outranking flows of each supplier (PROMETHEE I).

(a) Positive outranking flow and negative outranking flow are obtained using $\mathrm{Eq}$ (4). The flows of each supplier are summarized in Table 15.

(b) Determine the net outranking flow (PROMETHEE II) for each supplier.

Net flows are calculated using Eq (5). The results are presented in Table 16.

It is shown that supplier $A_{1}-$ MVG Food Marketing Sdn Bhd-is the best supplier by using the combination of linear and level function in the PROMETHEE method. All in all, the preference order can be written as $A_{1} \succ A_{3} \succ A_{4} \succ A_{2}$

\section{Discussion and conclusion}

This paper has proposed the preference in selecting the suppliers that deal with green organic products. Different types of preference functions have been used in the

Table 14 Preference index value

\begin{tabular}{lllll}
\hline & Supplier $A_{1}$ & Supplier $A_{1}$ & Supplier $A_{1}$ & Supplier $A_{1}$ \\
\hline Supplier $A_{1}$ & & 0.8782 & 0.8285 & 0.79905 \\
Supplier $A_{2}$ & 0 & & 0.1262 & 0.0631 \\
Supplier $A_{3}$ & 0.0588 & 0.35775 & & 0.1176 \\
Supplier $A_{4}$ & 0 & 0.37785 & 0 & \\
\hline
\end{tabular}


Table 15 PROMETHEE I Flow

\begin{tabular}{lll}
\hline Suppliers & $\phi^{+}(a)$ & $\phi^{-}(a)$ \\
\hline Supplier $A_{1}$ & 0.0835 & 0.0196 \\
Supplier $A_{2}$ & 0.0631 & 0.5379 \\
Supplier $A_{3}$ & 0.1781 & 0.3182 \\
Supplier $A_{4}$ & 0.1260 & 0.3266 \\
\hline
\end{tabular}

Table 16 Net flow value of suppliers

\begin{tabular}{lr}
\hline Suppliers & \multicolumn{1}{c}{ Net flow } \\
\hline Supplier $A_{1}$ & 0.0639 \\
Supplier $A_{2}$ & -0.4748 \\
Supplier $A_{3}$ & -0.1401 \\
Supplier $A_{4}$ & -0.2006 \\
\hline
\end{tabular}

Table 17 Summary of preference order of suppliers

\begin{tabular}{lll}
\hline Suppliers & $\begin{array}{l}\text { PROMETHEE (usual } \\
\text { criterion function) }\end{array}$ & $\begin{array}{l}\text { PROMETHEE (linear and } \\
\text { level functions) }\end{array}$ \\
\hline $\begin{array}{c}\text { Supplier } \\
A_{1}\end{array}$ & 1 & 1 \\
$\begin{array}{c}\text { Supplier } \\
A_{2}\end{array}$ & 4 & \\
$\begin{array}{c}\text { Supplier } \\
A_{3}\end{array}$ & 3 & 4 \\
$\begin{array}{c}\text { Supplier } \\
A_{4}\end{array}$ & 2 & 2 \\
\hline
\end{tabular}

implementation. The first net outflows and preference order are obtained using the usual criterion preference function, which is considered as the simplest function. The second net outflows and preference order are obtained using the combination of linear preference function and level preference functions. Both of these functions are chosen based on the nature of criteria. The final preference order of suppliers is summarized in Table 17.

It can be seen that supplier $A_{1}$ is consistently ranked as the first choice of supplier. Contrarily, the supplier $A_{2}$ has the weakest performance for both preference functions.
Furthermore, the net flow values of all the suppliers are analyzed and compared. Figure 5 shows the performance (net flows) of each supplier under two different preference functions.

The net flow values are used to see the suppliers' performance. Comparing the results in Fig. 2, it is noticed that supplier $A_{1}$ received the highest net flow value and supplier $A_{2}$ received the lowest net flow value for both preference functions. It is also good to note that supplier $A_{3}$ received the third highest net flow value in PROMETHEE (usual function) method and the second highest value in PROMETHEE (linear and level function) method. Finally, supplier $A_{4}$ received the second highest value in PROMETHEE (Usual Criterion function) method and the third highest value in PROMETHEE (linear and level function) method.

The PROMETHEE is one of the MCDM methods that is based on outranking. This method comprises many steps and choices of preference function as one of the significant steps. Many literatures acknowledged that there are at least six types of preference functions in PROMETHEE. However, the effect of type of preference functions to the final preference order is not fully discussed. This paper has investigated this issue where the usual function, linear function and level function were used as the preference functions of PROMETHEE. This investigation was implemented to the case study of green supplier selection in which four alternatives, five decision makers and seven criteria were the main structures of this MCDM method. It is found that the effect of these functions to the final preference order is not significant.

However, this study has some limitations, particularly in the choice of preference functions, its arithmetic operations and also the comparative analysis used. The choice of preference functions is limited to the three functions. Other preference functions or a modified preference function of PROMETHEE could be investigated in future research. The final preference order of this present study was obtained using subtraction operation which is sometimes looks very straightforward. Other arithmetic operations
Fig. 5 Net flow values of suppliers under usual function and linear and level function
Net Flow Value

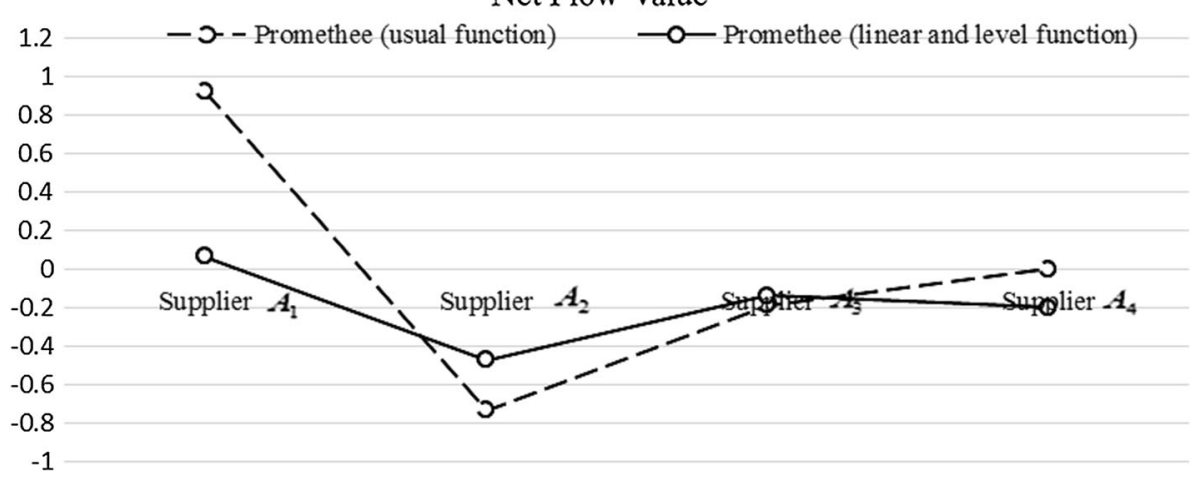


such as division combined with the concept of distance perhaps shed light on future research. This comparative study could also be implemented to other types of selection problems, such as manufacturing and service sectors.

\section{Compliance with ethical standards}

Conflict of interest The authors declare that they have no conflict of interest.

Open Access This article is distributed under the terms of the Creative Commons Attribution 4.0 International License (http://creative commons.org/licenses/by/4.0/), which permits unrestricted use, distribution, and reproduction in any medium, provided you give appropriate credit to the original author(s) and the source, provide a link to the Creative Commons license, and indicate if changes were made.

\section{References}

Albadvi A, Chaharsooghi SK, Esfahanipour A (2007) Decision making in stock trading: an application of PROMETHEE. Euro J Oper Res 177(2):673-683

Bali O, Kose E, Gumus S (2013) Green supplier selection based on IFS and GRA. J Inform Know Manag 3(2):158-176

Banaeian N, Mobli H, Fahimnia B, Nielsen IE, Omid M (2018) Green supplier selection using fuzzy group decision making methods: a case study from the agri-food industry. Comp Oper Res 89:337-347

Behzadian M, Kazemzadeh RB, Albadvi A, Aghdasi M (2010) PROMETHEE: a comprehensive literature review on methodologies and applications. Euro J Oper Res 200(1):198-215

Bilsel RU, Buyukozkan G, Ruan D (2006) A fuzzy preference ranking model for a quality evaluation of hospital web sites. Int J Intel Syst 21(11):1181-1197

Brans JP, Vincle P (1985) A preference ranking organization method. Mgmt Sci 31(6):647-656

Brans JP, Mareschal B, Vincke P (1984) PROMETHEE: a new family of outranking methods in MCDM. In: Brans J.P. (ed.) Oper Res IFORS 84: 477-490

Brans JP, Vincke P, Mareschal B (1986) How to select and how to rank projects: the PROMETHEE method. Euro J Oper Res 24:228-238

Dagdeviren M (2008) Decision making in equipment selection: an integrated approach with AHP and PROMETHEE. J Intell Manufac 19(4):397-406

Galankashi MR, Chegeni A, Soleimanynanadegany A, Ashkan M, Anjomshoae A, Helmi SA, Dargi A (2015) Prioritizing green supplier selection criteria using fuzzy analytical network process. J Sust Manuf 26(1):689-694

Geldermann JS, Pengler T, Rentz O (2000) Fuzzy outranking for environmental assessment. Case study: iron and steel making industry. Fuzzy Sets Syst 115(1):45-65

Govindan K, Sivakumar R (2016) Green supplier selection and order allocation in a low-carbon paper industry: integrated multicriteria heterogeneous decision-making and multi-objective linear programming approaches. Ann Oper Res 238(1-2):243-276

Guo Z, Liu H, Zhang D, Yang J (2017) Green supplier evaluation and selection in apparel manufacturing using a fuzzy multi-criteria decision-making approach. Sust (Switzerland) 9(4):650
Gurel O, Acar AZ, Onden I, Gumus I (2015) Determinants of the green supplier selection. J Soc Behav Sci 181(1):131-139

Hashemi SH, Karimi A, Tavana M (2015) An integrated green supplier selection approach with analytic network process and improved grey relational analysis. Int $\mathrm{J}$ Prod Econ 159(1):178-191

Hu YC, Chen CJ (2011) A PROMETHEE based classification method using concordance and discordance relations and its application to bankruptcy prediction. InfSci 181(22):4959-4968

Kannan D, Govindan K, Rajendran S (2014a) Fuzzy axiomatic design approach based green supplier selection: a case study from Singapore. J Clean Prod 96(1):194-208

Kannan D, Jabbour ABLDS, Jabbour CJC (2014b) Selecting green suppliers based on GSCM practices: using fuzzy TOPSIS applied to a Brazilian electronics company. Euro J Oper Res 233(2):432-447

Lee AHI, Kang HY, Hsu CF, Hung HC (2009) A green supplier selection model for high-tech industry. Expert Syst App 36(4):7917-7927

Luthra S, Garg D, Haleem A (2014) Green supply chain management. J Adv Mgmt Res 11(1):20-46

Mohammadi H, Farahani FV, Noroozi M, Lashgari A (2017) Green supplier selection by developing a new group decision-making method under type 2 fuzzy uncertainty. Int J Adv Manuf Tech 93(1-4):1443-1462

Mousakhani S, Nazari-Shirkouhi S, Bozorgi-Amiri A (2017) A novel interval type-2 fuzzy evaluation model based group decision analysis for green supplier selection problems: a case study of battery industry. J Clean Prod 168:205-218

Murat S, Kazan H, Coskun SS (2015) An application for measuring performance quality of schools by using the PROMETHEE multi criteria decision making method. Proc Soc Behav Sci 195(1):729-738

Nikouei MA, Oroujzadeh M, Mehdipour-Ataei S (2017) The PROMETHEE multiple criteria decision making analysis for selecting the best membrane prepared from sulfonated poly(ether ketone)s and poly(ether sulfone)s for proton exchange membrane fuel cell. Energy 119:77-85

Ozgen A, Tuzkaya G, Tuzkaya UR, Ozgen D (2011) A multi-criteria decision making approach for machine tool selection problem in a fuzzy environment. Int J Comp Intell Syst 4(4):431-445

Pang Q, Yang T, Li M, ShenYA (2017) Fuzzy-grey multicriteria decision making approach for green supplier selection in lowcarbon supply chain (2017) Math Prob Eng art. no. 9653261

Paulina G (2014) Logistics, operations, supply chain management and sustainability. Springer, Switzerland

Polat G (2015) Subcontractor selection using the integration of the AHP and PROMETHEE methods. J Civ Eng Manag 21(1):70

Qin J, Liu X, Pedrycz W (2017) An extended TODIM multi-criteria group decision making method for green supplier selection in interval type-2 fuzzy environment Euro J. Oper Res 258(2):626-638

Roghanian E, Alipour M (2014) A fuzzy model for achieving lean attributes for competitive advantages development using AHPQFD-PROMETHEE. J Ind Eng Int 10:68. https://doi.org/10. 1007/s40092-014-0068

Shi H, Chang Y, Cheng C (2016) A generalized PROMETHEE III with risk preferences on losses and gains. Int J Inf Manag Sci 27(2):117-127

Smet YD, Liduoh K (2013) An introduction to multi-criteria decision aid: the PROMETHEE and GAIA methods. J Bus Intell 138(1):150-176

Tavana M, Behzadian M, Pirdashti M, Pirdashti H (2013) A PROMETHEE-GDSS for oil and gas pipeline planning in the Caspian Sea basin. J Energy Econ 36(1):716-728 
Tomic V, Markovic D, Jovanovic M (2013) Application of PROMETHEE method on decision process in mines. Int $\mathrm{J}$ Eng 11(4):79

Tseng ML (2011) Green supply chain management with linguistic preferences and incomplete information. J Appl Soft Comput 11(8):4894-4903

Tuzkaya G, Gülsün B, Kahraman C, Özgen D (2010) An integrated fuzzy multi-criteria decision making methodology for material handling equipment selection problem and an application. Exp Syst Appl 37(4):2853-2863

Ulengin F, Topçu Y, Sahin SO (2001) An Integrated decision aid system for Bosporous water crossing problem. Euro J Oper Res 134:179-192

Vasić G (2018) Application of multi criteria analysis in the design of energy policy: space and water heating in households-City Novi Sad, Serbia. Energy Policy 113:410-419 